\title{
Effect of exotic invasive old world climbing fern (lygodium microphyllum) on soil properties
}

\author{
Pushpa G. Soti ${ }^{1}$ and Krish Jayachandran ${ }^{2}$ \\ ${ }^{l}$ Department of Biology, University of Texas Rio Grande Valley, Edinburg, TX 78539. USA. ${ }^{2}$ Department of \\ Earth and Environment, Florida International University, Miami, FL, 33199 USA.
}

\begin{abstract}
Old World climbing fern (Lygodium microphyllum) has become one of the most serious ecological threats to the integrity of the greater Everglades ecosystem of south Florida. In this study, we analyzed the effects of Old World climbing fern on surfacesoil characteristics at invaded sites in Florida. We compared soil characteristics of six invaded and adjacent uninvaded plots at three different locations. Our results show that the fern can grow and thrive in a wide range of soil types and the impact on the soil was site specific with effects being more prominent in sites with low nutrient status. Additionally, there were significant differences in the soil nutrient status and microbial population in the invaded and uninvaded sites. Sites with Old World climbing fern had significantly higher nutrient concentrations that correlated with higher soil organic matter. Overall our results indicate that this exotic pest plant can potentially alter its below ground environment to its own benefit by enhancing the soil nutrient status byadding soil organic matter.
\end{abstract}

Keywords: Invasive plants, nutrient cycle, $\mathrm{pH}$, soil organic matter, soil nutrients

\section{Introduction}

Invasion by exotic invasive plants has a substantial impact on the structure, function, and composition of the native communities (Evans et al. 2001; Ehrenfeld, 2003; Rice and Emery, 2003; Vila et al. 2011; Lanta et al. 2015). Existing literature provides evidence that invasive plant species can modify physical, chemical, and biological properties of the soil including inputs and cycling of nutrients (Ehrenfeld, 2003; Hawkes et al. 2005; Sperry et al. 2006), soil pH (Kourtev et al. 2003), soil organic matter and aggregation (Saggar et al. 1999). Invasive plants also modify the biotic composition of the soil by affecting the soil food web (Duda et al. 2003), total microbial communities (Kourtev et al. 2003), and fungal communities (Hawkes et al. 2006). Some invasive plants are also reported to exude allelochemicals which could inhibit soil borne pathogens, defend against disease, and repel insects (Yuan et al 2012; and references there in). However, the documented impacts of invasive species 
on soil characteristics are diverse. Most of the studies have reported increased soil nutrient stock in invaded sites compared to non-invaded sites creating a positive feedback benefiting invasive species (Duda et al.2003; Vanderhoeven et al.2005; Liao et al. 2008; Perkins, 2011). A meta-analysis of litter decomposition rates by Liao et al. (2008) showed that the litter decomposition rate of the invasive plants was on average, $117 \%$ faster than the co-occurring native species. However, Ehrenfeld (2010) demonstrated slower rates of litter decay in exotic species compared with the native plant species. This species-specific variation was attributed to be the most important factor in determining the decomposition rates (Hoorens et al. 2003), as each plant species has a unique biochemical composition, including the nitrogen concentration and carbon-to-nitrogen ratio. Gordon (1998) in her metaanalysis has shown that out of 31 species considered most invasive, 12-20 (39-64\%) potentially alter the ecosystem properties of geomorphology, hydrology, biogeochemistry, and disturbance in Florida.

Lygodium microphyllum (Old World Climbing Fern) is a highly invasive species distributed throughout the freshwater and moist habitatsof south Florida. It is common in cypress swamp, pine flatlands, wet prairies, sawgrass marshes, mangrove communities, and the Everglades tree islands (Pemberton and Ferriter, 1998). According to an estimate by (Ferriter and Pernas, 2006), L. microphyllum covers 183,080 acres in the entire South/Central Florida region. Managing L. microphyllum has been a significant challenge for land resource managers and researchers due to its extensive rapid invasion in natural areas of south Florida. Once established, L. microphyllum dominates both understory and overstory native wetland habitats, and has the ability to grow in varying hydrological (Gandiaga et al. 2009), nutrient (Volin et al. 2010), soil $\mathrm{pH}$ (Soti et al. 2014), and light gradients (Volin et al. 2004). Soti et al. (2014) have shown that L. micro- phyllum is highly dependent on mycorrhizal fungi for growth and phosphorus uptake which could highly enhance its invasiveness.

Above-ground changes caused by L. microphyllum in south Florida natural areas are obvious and have remained the focus of land managers and researchers, but below ground changes caused by the plant-soil feedback have not gained much research interest so far.However, forthe management of this exotic invasiveand restoration of invaded sites, it is essential to understand the direct and indirect impacts of L. microphyllum on soil processes and how these changes can influence the successful management of invaded areas. If L. microphyllum can successfully modify soil processes such as nutrient cycling, litter decomposition, and soil microbial communities, simply removing it may not be an effective management strategy. Furthermore, it is necessary to assess the effects of soil modification by L. microphyllum on the invasability of plant communities, whether this modification facilitates other invasive species and if it hasa negative impact on the native species. The aim of this paper is to obtain baseline information on how L. microphyllum alters the physical, chemical, and microbial characteristics of the invaded sites, which would help to better understand and interpret effects of various management techniques usedto control this pest plant species. We compared an invaded and a nearby non-invaded site to examine the impacts of L. microphyllum invasion on the topsoil chemistry and microbial populations at three sites with different soil characteristics.

\section{Methods}

\subsection{Sampling sites}

Two sites in south Florida were selected for the comparison of soil characteristics: Tree Tops Park (Bro- 
ward county) and Jonathan Dickinson Park (Martin county), and one site in central Florida, the Trustcorp/ Tiedtke property (Lake County). These sites were paired to include one plot with L. microphyllum and another with native plants.To minimize the probability of pre-existing difference in the soil characteristics, the sites were selected based on the following criteria: 1) a well-established monospecific population; 2) sites that had not undergone any management activities for at least the last five years; 3) homogeneous soil type under both the native and invasive plants (texture and parent material); and 4) adjacent plots with native plants. 5) no known difference in the disturbance status at the plot with invasive plants and corresponding invasive plot. These criteria are similar to the ones used by used by Vanderhoeven et al. (2005). Site locationand dominant vegetation in the sampling sites are given in Table 1.

Table 1. Site locations, vegetation, and site type.

\begin{tabular}{llll}
\hline Site & Coordinates & Dominant species in the invaded sites & Site Type \\
\hline $\begin{array}{l}\text { Tree Tops } \\
\text { Park }\end{array}$ & $26^{\circ} 4^{\prime} 0.04^{\prime \prime} \mathrm{N}$, & $\begin{array}{l}\text { Chrysobalanus icaco, Osmunda regalis var. } \\
\text { spectabilis, Annona glabra }\end{array}$ & $\begin{array}{l}\text { County Park, disturbed } \\
\text { habitat, poorly drained }\end{array}$ \\
& $80^{\circ} 16^{\prime} 5.88^{\prime \prime} \mathrm{W}$ & & \\
Jonathan & $27^{\circ} 0^{\prime} 37.33^{\prime \prime} \mathrm{N}$, & Pinus elliottii, Myrica cerifera, Ilex cassine, & State Park, well drained, \\
Dickinson & $80^{\circ} 7^{\prime} 20.28^{\prime \prime} \mathrm{W}$ & Serenoa repens & undisturbed habitat \\
Central & $28^{\circ} 23^{\prime} 4.03^{\prime \prime} \mathrm{N}$, & Pinus elliottii, Quercus geminata, Quercus nigra, & Private property, sand \\
Florida & $81^{\circ} 44^{\prime} 41.30^{\prime \prime} \mathrm{W}$ & Serenoa repens & mine spoil \\
& & &
\end{tabular}

\subsection{Soil sampling and analysis}

At each sampling site, six $1 \mathrm{~m} \times 1 \mathrm{~m}$ plots were selected randomly and soil from the $10-15 \mathrm{~cm}$ deep zone was collected from each of the four corners and the center of each plot with a soil corer ( $18 \mathrm{~mm}$ ) and mixed homogeneously into one bulk sample for each plot. The soil samples from south Florida were transported to the laboratory in a cooler and the samples from central Florida were cooled to $4{ }^{\circ} \mathrm{C}$ and shipped overnight. A portion of the soil samples from all sites were stored in a $4{ }^{\circ} \mathrm{C}$ refrigerator until analysis for biological measure- ments. A small portion of each soil sample was air dried and passed through a $2 \mathrm{~mm}$ sieve for analysis of physicochemical properties. Those subsamples were then ground to fine powder with a mortar and pestle, and stored at room temperature in air-tight containers for further analysis of nutrients and trace elements. The soil $\mathrm{pH}$ was measured with a $\mathrm{pH}$ meter (soilsolution ratio 1:2 in DI water), texture was measured by the hydrometer method, and total organic matter was measured based on the standard loss-on-ignition method $\left(500{ }^{\circ} \mathrm{C}, 5\right.$ hours; Storer, 1984). Total C and $\mathrm{N}$ were measured with a Truspec $\mathrm{CN}$ analyzer. Total $\mathrm{Ca}, \mathrm{Fe}, \mathrm{Al}, \mathrm{Mg}, \mathrm{K}, \mathrm{Mn}$, 
and $\mathrm{P}$ were measured with an ICP-MS at USDA, ARS Laboratory, Homestead, Florida after following the acid digestion Method 3050 (USEPA, 1996). One gram of each finely ground soil sample was transferred to a large glass tube and mixed with $10 \mathrm{ml}$ of $30 \% \mathrm{HNO}_{3}$. The tubes were covered with a vapor recovery system and heated to $95 \pm$ $5^{\circ} \mathrm{C}$ and refluxed for 10 minutes without boiling under the hood in a heating block maintained with a Partlow Mic 6000 Profile Process Controller. After cooling to $40{ }^{\circ} \mathrm{C}, 5 \mathrm{ml}$ of concentrated $\mathrm{HNO}_{3}$ was added and the sample was heated again until no brown fumes were given off. After cooling to $40{ }^{\circ} \mathrm{C}, 2 \mathrm{ml}$ of DI water and $3 \mathrm{ml}$ of $30 \% \mathrm{H}_{2} \mathrm{O}_{2}$ was added to each tube and heated until the effervescence subsided. The samples were cooled and diluted to $50 \mathrm{ml}$ with DI water, centrifuged at 2000 rpm for 10 minutes and filtered with Whatman No. 41 filter paper.

The total colony-forming-units (CFU) of bacteria and fungi were determined by the standard dilution spread plate method as described by Seely and VanDemark (1981). The dry equivalent of one-gram soil was mixed in $9 \mathrm{ml}$ sterile water (autoclaved) and was diluted serially. Samples were vigorously mixed during dilution to assist in dislodging the bacteria from the soil particles. A serial dilution of $10^{-2}, 10^{-3}, 10^{-4}$, and $10^{-5}$ was made for fungi and $10^{-4}, 10^{-5}, 10^{-6}$, and $10^{-7}$ for bacteria. A total of $100 \mu \mathrm{l}$ of diluted soil suspension was spread on three plates per soil sample for both bacteria and fungi at each dilution level. Nutrient agar containing cycloheximide solution (to prevent fu- gal growth) was used for bacteria and Rose Bengal Agar (RBA) with streptomycine sulphate (to prevent bacteria growth) was used for the estimation of fungal colonization. Sterilized water was spread on the agar plates that were used as controls.

\subsection{Data analysis}

Differences in soil characteristics between the invaded and uninvaded plots were compared by means of paired t-tests. Additionally, a two-way ANOVA was done with site and vegetation type (invaded and uninvaded) as the fixed main effects for selected soil parameters. Pearson's correlation analysis was done with all sites pooled to determine relationships between the measured soil variables. Differences are reported as significant for tests with $P$-values $\leq 0.05$. All the parameters were analyzed with SAS Version 9.2 software.

\section{Results}

Our results show that there was a clear contrast between the rhizosphere soils from the three sites (Table 2, $3 \& 4$ ). All the study sites were acidic (soil pH 4.95-6.36), but the sitesin central Florida and atTree Tops Park had lower soil pH compared to the sites at Jonathan Dickinson Park. Likewise, the soil texture differed among the sites; Jonathan Dickinson sites had sandy soils, while the soils in central Florida were clayey, and the soil at Tree Tops Park was sandy loam. Soil organic matter was highest at Tree Tops Park and was lowest at Jonathan Dickinson Park. 
Table 2. Comparison of the topsoil chemical characteristics (means with standard deviations in parentheses) at the three sites with and without L. microphyllum.

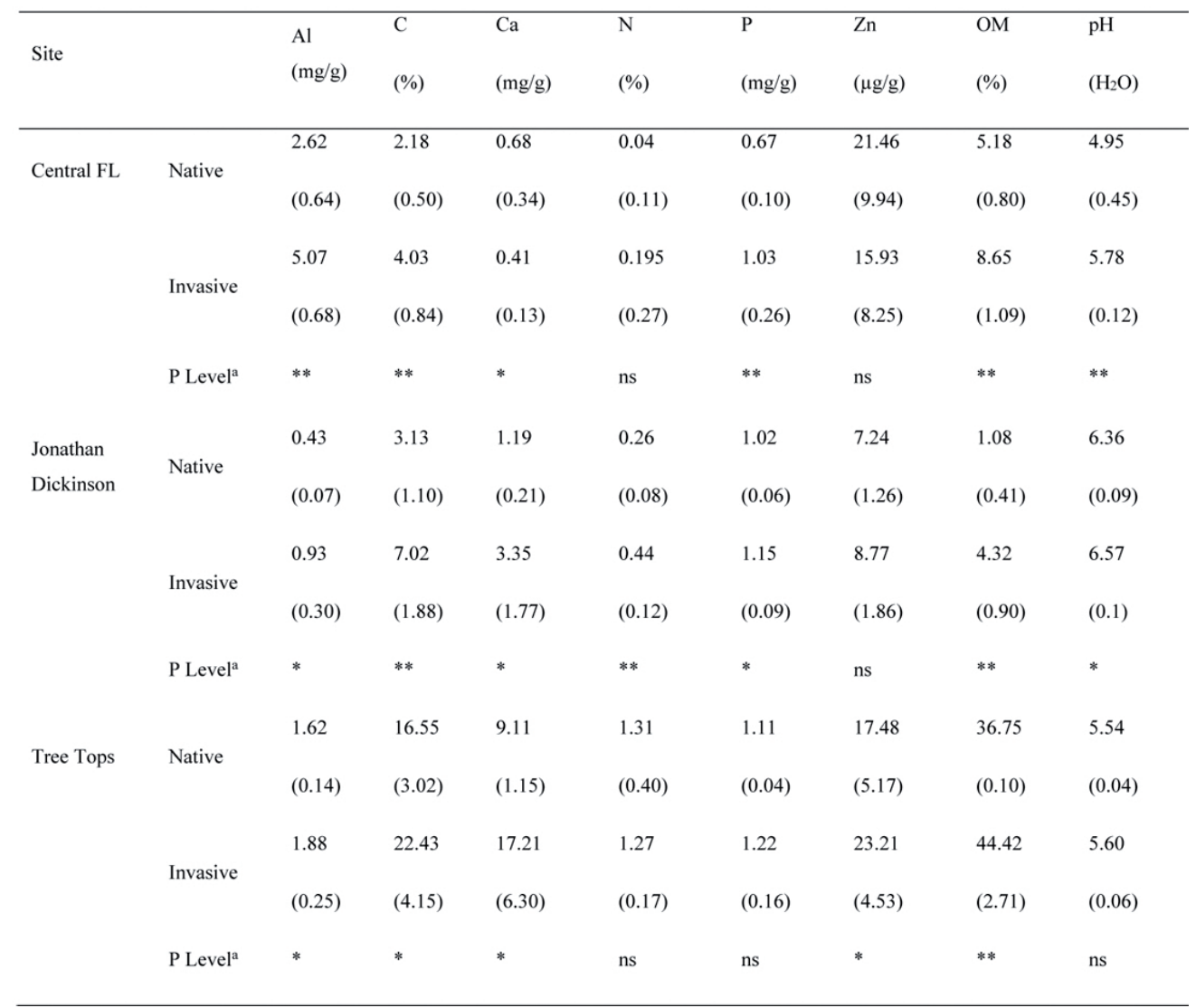

${ }^{a}$ Significance for paired t-test, ns: not significant; Probability levels: *: $\mathrm{P}<0.05 ; * * \mathrm{P}<0.01 ; * * * \mathrm{P}<0.0001 .0 \mathrm{M}$ : soil organic matter.

Significant differences were found in the soil chemistry among invaded and non-invaded soils in different between the invaded plots and non-invaded plots in all three sampling sites (Table 2). Most notably, there were significant differences in the total soil $\mathrm{Al}, \mathrm{C}, \mathrm{Ca}$, and $\mathrm{OM} \%$ at all three sites (Table 2). At all the sites, soils invaded by L. microphyllum had higher concentrations of $\mathrm{Al}, \mathrm{Ca}, \mathrm{C}$ and organic matter.Differences in the concentrations of $\mathrm{N}, \mathrm{P}, \mathrm{Zn}$, and $\mathrm{pH}$ were sitespecific. Soils under native vegetation were gener- ally more acidic; this was statistically significant at the central Florida and Jonathan Dickinson sites but was not statistically significant at the Tree Tops Park site. There was no significant difference in the $\mathrm{Cu}, \mathrm{Fe}$, $\mathrm{K}, \mathrm{Mg}$, and $\mathrm{Mn}$ concentrations under native vegetation and L. microphyllumat all the three sites (data not shown). The most significant effects on soil characteristics were seen at sites with the lowest nutrient concentrations. 
Two-way ANOVA results of sampling sties, plant type (native/invasive) and their interaction (Table 3), shows that there was a significant difference in the sites soil chemistry. Plant type had a significant impact on soil Al, $\mathrm{C}, \mathrm{Ca}, \mathrm{K}, \mathrm{Mg}, \mathrm{P}, \mathrm{OM}$, and $\mathrm{pH}$ while there was no significant impact on $\mathrm{Cu}, \mathrm{Fe}, \mathrm{N}$, and Zn. Similarly, the interaction of site and plant had a significant impact only on soil $\mathrm{Al}, \mathrm{Ca}, \mathrm{Mg}, \mathrm{OM}$, and $\mathrm{pH}$.

Though it was site specific, L. microphyllum invasion callused a shift of the bacteria and fungi CFUs (Table 4). Largest CFUs of bacteria were observed under native plants in the Tree Tops Park site $\left(282.5 \times 10^{6}\right)$ while the lowest CFUs were in the Jonathan Dickinson Park site under L. microphyllum $\left(39 \times 10^{6}\right)$. The bacteria population was significantly higher under the native species compared to L. microphyllum in two sites; the difference was not statistically significant at the central Florida site. On the other hand, the fungal population was significantly higher under L. microphyllum compared to the native plants at all three sites. The Central FL site under
L. mycrophyllum has the highest fungal CFUs ( $88.83 \mathrm{x}$ $\left.10^{3}\right)$, while it was lowest under native plants at Jonathan Dickinson Park site $\left(33.5 \times 10^{3}\right)$.

Pearson's correlation analysis among the soil variables indicated that there was a strong correlation between soil nutrients and soil organic matter (Table 5). There a strong negative correlation between soil $\mathrm{OM}$ and $\mathrm{Al}$ concentration $(\mathrm{r}=-0.030, p<0.05)$ and strong positive correlation with $\mathrm{C}, \mathrm{Ca}$, and $\mathrm{N}(\mathrm{r}=0.928,0.874,0.875 ; p<0.0001)$. Soil $\mathrm{pH}$ had negative correlation with $\mathrm{Al}$ concentration $(\mathrm{r}=-0.385, p<0.05), \mathrm{Zn}(\mathrm{r}=-0.716)$, and positive correlation with total $\mathrm{P}(\mathrm{r}=-0.716, p<0.0001)$. Total bacteria CFUs was positively correlated with $\mathrm{C}(\mathrm{r}=0.463$, $p<0.01), \mathrm{Ca}(\mathrm{r}=0.339, p<0.05), \mathrm{N}(\mathrm{r}=0.533, \mathrm{p}<0.01)$ $\mathrm{OM}(\mathrm{r}=0.651, p<0.0001)$ and $\mathrm{Zn}(\mathrm{r}=0.469, p<0.01)$, and negatively correlated with soil $\mathrm{pH}(\mathrm{r}=-0.632, \mathrm{p}$ $<0.0001)$. Similarly, total fungi CFUs was positively correlated with soil $\mathrm{Al}(\mathrm{r}=0.776, p<0.0001)$ and $\mathrm{Zn}(\mathrm{r}=$ $0.524, p<0.01)$, and negatively correlated with $\mathrm{pH}(\mathrm{r}=$ $-0.432, p<0.01)$.

Table 3. Results of two-way analyses of variance (ANOVA) with degree of freedom (DF), F-value and probability levels for the effects of site, plant type and the interaction of the two on the soil characteristics.

\begin{tabular}{|c|c|c|c|c|c|c|c|c|c|c|c|}
\hline Source & $\mathrm{DF}$ & $\mathrm{Al}$ & $\mathrm{C}$ & $\mathrm{Ca}$ & $\mathrm{Cu}$ & $\mathrm{Fe}$ & $\mathrm{K}$ & $\mathrm{Mg}$ & $\mathrm{Mn}$ & $\mathrm{N}$ & $\mathrm{P}$ \\
\hline \multirow{2}{*}{ Site } & \multirow{2}{*}{2} & 195.3 & 179.89 & 75.91 & 46.87 & 19.5 & 10.09 & 28.59 & 3.47 & 99.65 & 16.78 \\
\hline & & $* * *$ & $* * *$ & $* * *$ & $* * *$ & $* * *$ & $* * *$ & $* * *$ & $*$ & $* * *$ & $* * *$ \\
\hline \multirow{2}{*}{ Plant } & \multirow{2}{*}{1} & 65.24 & 25.33 & 13.52 & 0.14 & 2.55 & 14.74 & 12.16 & 2.54 & $1.9 \mathrm{~ns}$ & 19.04 \\
\hline & & $* * *$ & $* * *$ & $* *$ & $\mathrm{~ns}$ & ns & $* * *$ & $* *$ & ns & & $* * *$ \\
\hline Site $\mathrm{x}$ & \multirow{2}{*}{2} & 27.05 & \multirow[t]{2}{*}{$2.29 \mathrm{~ns}$} & 7.53 & 0.52 & 0.55 & 0.83 & 4.19 & 3.31 & 0.94 & \multirow[t]{2}{*}{$2.8 \mathrm{~ns}$} \\
\hline Plant & & $* * *$ & & $* *$ & $\mathrm{~ns}$ & ns & ns & * & ns & ns & \\
\hline Source & DF & OM & $\mathrm{Z}$ & & $\mathrm{pH}$ & & & & & & \\
\hline \multirow[t]{2}{*}{ Site } & \multirow[t]{2}{*}{2} & \multicolumn{2}{|c|}{2132.23} & 14.73 & \multicolumn{2}{|c|}{102.88} & & & & & \\
\hline & & $* * *$ & & $* * *$ & $* *$ & & & & & & \\
\hline \multirow[t]{2}{*}{ Plant } & \multirow[t]{2}{*}{1} & \multicolumn{2}{|c|}{85.22} & 0.08 & \multicolumn{2}{|c|}{30.13} & & & & & \\
\hline & & \multicolumn{2}{|l|}{$* * *$} & $\mathrm{~ns}$ & \multicolumn{2}{|c|}{$* * *$} & & & & & \\
\hline Site $X$ & 2 & \multicolumn{2}{|c|}{7.68} & 2.66 & \multicolumn{2}{|c|}{12.29} & & & & & \\
\hline Plant & \multicolumn{3}{|c|}{$* *$} & ns & \multicolumn{2}{|c|}{$* * *$} & & & & & \\
\hline
\end{tabular}


Table 4. Comparison of the topsoil microbial populations (means with standard deviations in parentheses) at the three sites with and without L. microphyllum.

\begin{tabular}{|c|c|c|c|}
\hline & & TBC & TFC \\
\hline \multirow{7}{*}{ Central FL } & \multirow{3}{*}{ Native } & 152.5 & 61.16 \\
\hline & & & \\
\hline & & $(16.42)$ & $(9.82)$ \\
\hline & \multirow{3}{*}{ Invasive } & 138.33 & 88.83 \\
\hline & & & \\
\hline & & $(10.78)$ & $(3.31)$ \\
\hline & P Level $^{\mathrm{a}}$ & $\mathrm{ns}$ & $* *$ \\
\hline \multirow{5}{*}{$\begin{array}{l}\text { Jonathan } \\
\text { Dickinson }\end{array}$} & \multirow{2}{*}{ Native } & 57.33 & 33.5 \\
\hline & & $(7.25)$ & (4.84) \\
\hline & \multirow{3}{*}{ Invasive } & 39 & 46.66 \\
\hline & & & \\
\hline & & $(4.28)$ & $(7.76)$ \\
\hline \multirow{8}{*}{ Tree Tops } & $\mathrm{PLevel}^{\mathrm{a}}$ & $* *$ & $*$ \\
\hline & \multirow{3}{*}{ Native } & 282.5 & 51.66 \\
\hline & & & \\
\hline & & (11.07) & $(5.68)$ \\
\hline & \multirow{3}{*}{ Invasive } & 143.66 & 73.83 \\
\hline & & & \\
\hline & & (13) & $(12.27)$ \\
\hline & P Level $^{\mathrm{a}}$ & $* * *$ & $* *$ \\
\hline
\end{tabular}

${ }^{\text {a }}$ Significance for paired t-test, ns: not significant; Probability levels: *: $\mathrm{P}<0.05 ; * * \mathrm{P}<0.01$; $* * * \mathrm{P}<0.0001$.TBC: total bacterial count (count $\times 10^{6} \mathrm{~g}^{-1} \mathrm{dw}$ ); TFC: total fungal count (count $\times 10^{3} \mathrm{~g}^{-1} \mathrm{dw}$ ). 
Table 5. Pearson's correlation coefficients between the selected soil parameters with all sites pooled.

\begin{tabular}{|c|c|c|c|c|c|c|c|c|c|c|}
\hline & $\mathrm{Al}$ & C & $\mathrm{Ca}$ & $\mathrm{N}$ & $\mathrm{OM}$ & P & $\mathrm{Zn}$ & $\mathrm{pH}$ & $\mathrm{TBC}$ & TFC \\
\hline Al & - & & & & & & & & & \\
\hline \multirow[t]{2}{*}{ C } & -0.171 & - & & & & & & & & \\
\hline & ns & & & & & & & & & \\
\hline \multirow[t]{2}{*}{$\mathrm{Ca}$} & -0.173 & 0.892 & - & & & & & & & \\
\hline & ns & $* * *$ & & & & & & & & \\
\hline \multirow[t]{2}{*}{$\mathrm{N}$} & -0.241 & 0.894 & 0.792 & - & & & & & & \\
\hline & ns & *** & *** & & & & & & & \\
\hline \multirow[t]{2}{*}{ OM } & -0.030 & 0.928 & 0.874 & 0.875 & - & & & & & \\
\hline & * & *** & $* * *$ & $* * *$ & & & & & & \\
\hline \multirow[t]{2}{*}{$\mathrm{P}$} & -0.099 & 0.542 & 0.571 & 0.524 & 0.433 & - & & & & \\
\hline & ns & $* *$ & $* *$ & $* *$ & $* *$ & & & & & \\
\hline \multirow[t]{2}{*}{$\mathrm{Zn}$} & 0.255 & 0.389 & 0.447 & 0.325 & 0.470 & -0.151 & - & & & \\
\hline & ns & * & $* *$ & ns & $* *$ & ns & & & & \\
\hline \multirow[t]{2}{*}{$\mathrm{pH}$} & -0.385 & -0.127 & -0.142 & -0.069 & -0.321 & 0.457 & -0.716 & - & & \\
\hline & * & ns & ns & ns & ns & $* *$ & $* * *$ & & & \\
\hline \multirow[t]{2}{*}{ TBC } & 0.254 & 0.463 & 0.339 & 0.533 & 0.651 & -0.057 & 0.469 & -0.632 & - & \\
\hline & ns & $* *$ & * & $* *$ & $* * *$ & ns & $* *$ & $* * *$ & & \\
\hline \multirow[t]{2}{*}{ TFC } & 0.776 & 0.190 & 0.135 & 0.029 & 0.270 & -0.035 & 0.524 & -0.432 & 0.255 & - \\
\hline & $* * *$ & ns & ns & ns & $\mathrm{ns}$ & ns & $* *$ & $* *$ & ns & \\
\hline
\end{tabular}

Probability levels: *: $\mathrm{P}<0.05 ; * * \mathrm{P}<0.01 ; * * * \mathrm{P}<0.0001$. Coefficients higher than 0.75 are in bold.

OM: soil organic matter; TBC: total bacterial count; TFC: total fungal count.

\section{Discussion}

In this study we compared soil from three different sites with contrasting soil characteristics and land use history; thus, the differences observed in soil measured soil parameters among these sites are in large part explained by this. The site effect was highly significant for all the soil parameters analyzed, indicating that L. microphyllum can adapt to and thrive in sites with a significant variation in nutrients as well as other soil characteristics. Additionally, our results indicate $L$ microphyllum has a significant impact on the soil characteristics, and the effect is highly dependent on existing soil conditions. Impacts on the total nutrient pool and microbial community structure are considered the most prominent effects of invasive species in the ecosystem. Overall, our results show higher total soil nutrient pool in the rhizosphere of L. microphyllum compared to the rhizosphere of adjacent native species. These results follow the general trend reported by various researchers, where the nutrient pools in the invasive species rhizosphere are significantly increased compared to the coexisting natives (Duda et al. 2003; Vanderhoven, 2005; Dassonville et al. 2008; Liao et al. 2008; Perkins, 2011). This effect was most evident at sites with lowest nutrient concentration. As reported by Ehrenfeld (2003) and Liao et al. (2008), this may be the direct effect of higher quality (lower C:N and C: P ratios) litter added to the rhizosphere (Soti et al. unpublished data) which may result in faster turnover rates and increased nutrient availability. 
Our results also show a difference in the rhizosphere microbial community which contributes directly to plant fitness, nutrient acquisition and stress tolerance. There was an increase on the fungi populations under L. microphyllum compared to the native species, while a decline in the bacteria population. This could be the result of the difference in the carbon input from plant to soil through root exudation (Merino et al. 2015; Violante and Caporale, 2015). Further analysis on the type of microbes and the role of allelochemicals, which are reported to be an important determinant for invasive success of exotic plants (Bais et al. 2003), in regulating the soil microbial community structure is necessary, but our results provide some evidence that L. microphyllum could regulate the structure of soil microbial communities in its rhizosphere.

Additionally, Since the Tree Tops site was a seasonally flooded site, this site had a high percentage of soil organic matter, which is common in the Florida Everglades. Soil organic matter was significantly higher in the invaded sites compared to the non-invaded sites. Soil organic matter was strongly correlated to the available soil nutrients which indicates that the difference in the organic matter inputs to the soil under the natives and L. microphyllum could influence the difference in the nutrient availability.

Although any pre-existing differences in the plots with and without L. microphyllum cannot be disregarded with complete certainty, we believe that the differences in the soil characteristics between the invaded and uninvaded plots could be the result of difference in plant species in them.

\section{Conclusion}

L. microphyllum invasion is still expanding and preand post-invasion comparison could provide a better insight on the alternative hypothesis that persisting differences in site leading to exotic species invasion.
Successful management of habitats invaded by exotic plant species requires a prior knowledge of whether the invaders have significantly altered the ecosystem (Walker and Smith, 1997) because soil properties such as texture, $\mathrm{pH}$, and organic matter content influence herbicide efficiency and therefore control success. Along with the added organic matter, nutrients, and changes in the $\mathrm{pH}$ of the soil, other specific ecosystem process as outlined by Gordon (1998) could also be influenced by various exotic invasive species that create positive feedback for themselves and future invaders. Additionally, mechanisms such as production of allelochemicals, and changes in the microbial communities merit future research to achieve successful control of L. microphyllum and other exotic invasive species in the Everglades.

\section{Acknowledgement}

This research was supported by the Dissertation Evidence Acquisition Fellowship, to Pushpa Soti from the Graduate School, Florida International University. Helpful comments on the manuscript were made by, Suzanne Koptur, and Michael Sukop. We also thank Stewart T. Reed, USDA, ARS, Miami, Florida for his help in analyzing the samples

\section{Reference}

Bais, H.P.,Vepachedu, R., Gilroy S., Callaway, R.M., Vivanco, J.M.2003.Allelopathy and exotic plant invasion: from molecules and genes to species interactions. Science. 301, 1377-1380.

Dassonville N., Vanderhoeven S., Vanparys V., Hayez M., Gruber W.,Meerts, P. 2008. Impacts of alien invasive plants on soil nutrients are correlated with initial site conditions in NW Europe. Oecologia. 157, 131-140. 
Duda, J. J., Freeman, D.C., Emlen, J.M., Belnap, J., Kitchen, S.G., Zak, J.C., Sobek, E., Tracy, M., Montante, J. 2003. Differences in native soil ecology associated with invasion of the exotic annual chenopod, Halogeton glomeratus. Biol. Fertility Soils. 38, 72-77.

Ehrenfeld, J.G., 2010. Ecosystem consequences of biological invasions. Annual Review of Ecology. Evolution and Systematics. 41, 59-80.

Ehrenfeld, J.G. 2003. Effects of exotic plant invasions on soil nutrient cycling processes. Ecosystems. 6, 503-523.

Evans, R., Rimer, R., Sperry, L., Belnap, J.2001. Exotic plant invasion alters nitrogen dynamics in an arid grassland. Ecol. Appl. 11:1301-1310.

Ferriter, A., Pernas, T. 2006. An explosion in slow motion: Tracking the spread of Lygodium microphyllum in Florida. Wildland Weeds. 9, 7-9.

Gandiaga, S., Volin, J., Kruger, E., Kitajima, K. 2009. Effects of hydrology on the growth and physiology of an invasive exotic, Lygodium microphyllum (old world climbing fern). Weed Res. 49, 283-290.

Gordon, D.R. 1998. Effects of invasive, non-indigenous plant species on ecosystem processes: Lessons from Florida. Ecol. Appl. 8, 975-989.

Hawkes, C.V., Belnap, J., D’Antonio, C., Firestone, M.K. 2006. Arbuscular mycorrhizal assemblages in native plant roots change in the presence of invasive exotic grasses. Plant Soil. 281, 369-380.

Hawkes, C.V., Wren, I.F., Herman, D.J., Firestone, M.K. 2005. Plant invasion alters nitrogen cycling by modifying the soil nitrifying community. Ecol. Lett. 8, 976-985.

Hoorens, B., Aerts, R., Stroetenga, M. 2003. Does initial litter chemistry explain litter mixture effects on decomposition?. Oecologia. 137, 578-586.
Kourtev, P., Ehrenfeld, J., Häggblom,M. 2003. Experimental analysis of the effect of exotic and native plant species on the structure and function of soil microbial communities. Soil Biol. Biochem. 35, 895-905.

Lanta, V., Hyvönen, T., Norrdahl, K. 2015. Leaf litter decomposition of nonnative shrub species in nonnative and native shrub environments: a field experiment with three Rosaceae shrubs. Invasive Plant Science and Management. 8(1), 81-89.

Liao, C., Peng, R., Luo, Y., Zhou, X.,Wu, X., Fang, C., Chen, J., Li, B. 2008. Altered ecosystem carbon and nitrogen cycles by plant invasion: A meta-analysis. New Phytol. 177, 706-714.

Merino, C., Nannipieri, P., Matus, F. 2015. Soil carbon controlled by plant, microorganism and mineralogy interactions. Journal of soil science and plant nutrition.15(2), 321-332.

Pemberton, R.W., Ferriter, A.P. 1998.Old world climbing fern (Lygodium microphyllum), a dangerous invasive weed in Florida. Am. Fern J. 165-175.

Perkins, L.B., Johnson, D.W., Nowak, R.S. 2011. Plant-induced changes in soil nutrient dynamics by native and invasive grass species. Plant Soil. 345, 365-374.

Rice, K.J., Emery, N.C. 2003. Managing microevolution: Restoration in the face of global change. Frontiers in Ecology and the Environment. 1, 469478.

Saggar, S., McIntosh, P., Hedley, C., Knicker, H.1999. Changes in soil microbial biomass, metabolic quotient, and organic matter turnover under Hieracium (H. pilosella L.). Biol. Fertility Soils. 30, 232-238.

Seeley, H.W., VanDemark, P.J. 1962. Microbes in action. A laboratory manual of microbiology. Microbes in action. A laboratory manual of microbiology. 
Sperry, L., Belnap, J., Evans, R. 2006. Bromus tectorum invasion alters nitrogen dynamics in an undisturbed arid grassland ecosystem. Ecology. 87, 603-615.

Storer, D.A. 1984. A simple high sample volume ashing procedure for determination of soil organic matter. Communications in Soil Science \& Plant Analysis. 15, 759-772.

USEPA Method 3050. 1996. Acid digestion of sediments, sludges, and soils.

Vanderhoeven, S., Dassonville, N., Meerts, P. 2005. Increased topsoil mineral nutrient concentrations under exotic invasive plants in Belgium. Plant Soil. 275, 169-179.

Vilà, M., Espinar, J.L., Hejda, M., Hulme, P.E., Jarošík, V., Maron, J.L., Pergl, J.,Schaffner, U., Sun, Y., Pyšek, P. 2011. Ecological impacts of invasive alien plants: A meta-analysis of their effects on species, communities and ecosystems. Ecol. Lett. 14, 702-708.
Violante, A., Caporale, A.G. 2015. Biogeochemical processes at soil-root interface. Journal of Soil Science and Plant Nutrition, 15(2) 422-448.

Volin, J.C., Kruger, E.L., Volin, V.C., Tobin, M.F., Kitajima, K. 2010. Does release from natural belowground enemies help explain the invasiveness of Lygodium microphyllum? A cross-continental comparison. Plant Ecol. 208, 223-234.

Volin, J.C., Lott, M.S., Muss, J.D., Owen, D. 2004. Predicting rapid invasion of the Florida Everglades by old world climbing fern (Lygodium microphyllum). Divers. Distrib. 10, 439-446.

Walker, L.R., Smith, S.D. 1997. Impacts of invasive plants on community and ecosystem properties. In: Assessment and management of plant invasions. Springer New York. pp.69-86.

Yuan, Y., Wang, B., Zhang, S., Tang, J., Tu, C., Hu, S., Yong, J.W., Chen, X. 2012. Enhanced allelopathy and competitive ability of invasive plant Solidago canadensis in its introduced range. Journal of Plant Ecology. 